\title{
Cultural Empowerment and Language: Teaching Spanish to the Socially Disadvantaged Amazigh Population through the Alehop Programme ${ }^{1}$
}

\author{
Elvira Molina-Fernández ${ }^{1}$, Fernando Barragán Medero $^{2}$, David Pérez-Jorge ${ }^{2} \&$ Francisco Oda-Ángel $^{3}$ \\ ${ }^{1}$ Professor at Universidad de Granada (UGR), Facultad de Educación y Humanidades, Departamento de \\ Pedagogía, Melilla, Spain \\ ${ }^{2}$ Professor at Universidad de La Laguna (ULL), Faculty of Education, Department of Didactics and Educational \\ Research, Tenerife, Spain \\ ${ }^{3}$ Professor of Sociology Universidad Rey Juan Carlos, Madrid, Spain \\ Correspondence: David Pérez-Jorge, Faculty of Education, Department of Didactics and Educational Research. \\ Universidad de la Laguna (ULL), Tenerife, Canary Islands, Spain. E-mail: dpjorge@ull.edu.es
}

Received: July 24, 2017

Accepted: August 17, $2017 \quad$ Online Published: September 28, 2017

doi:10.5539/ass.v13n10p43

URL: https://doi.org/10.5539/ass.v13n10p43

\begin{abstract}
This article describes an action research programme designed to resolve classroom problems, in preschool and primary education, related to the use of Spanish as a hegemonic language in a bilingual context in which students are from the Amazigh culture. The Alehop programme aims to motivate students to learn and the results demonstrate that this classroom innovation is possible. Moreover, the use of everyday life situations and typical problems helps and favours enquiry-based learning. Intercultural school life without violence is shown to be possible. Strategies include giving voice to the students, addressing relevant social issues, and creating an environment of trust and collaboration. An evaluation of the results validates a methodology that encourages cultural and linguistic diversity, and points to a need to respect the autonomy, freedom and human rights of students in politically and economically disadvantaged conditions. Empowerment is linked to the autonomy of students and teachers.
\end{abstract}

Keywords: Interculturality, language, learning, culture, preschool and primary education, empowerment.

\section{Introduction}

The concept of culture has been defined from multiple perspectives (Tylor, 1871; Lévi-Strauss, 1958; Keesing, 1993; Grimson, 2008; Harris \& Sempere, 2000; Harris, 2011), which have converted the term into a concept with multiple signifiers that vary according to the emphasis placed on the elements that define it.

It may be understood as adaptation, evolution - flexible or closed - but it is always subject to processes of change in the same way that it tries to preserve, through different mechanisms, what may be considered to be enduring aspects of each different culture. The central question is who represents the culture, which collective preserves it, and who is interested in transforming it.

From the perspective of androcentric sociology, politically motivated views have been propounded, which have made women and their rights invisible since the definitions of Durkheim (1976) and Parsons (1973), who defined culture as a system of values, meanings and knowledge introduced by men through primary socialisation. They are homogeneous constructions that exclude the diversity that is present in the educational system. Erickson (1987) contended that cultural differences could become instruments of discrimination and resistance. In fact, the political suprastructure and microstructure both produce a cognitive dissonance within the educational reality linked to the diversity that is experienced as a consequence of the nationalisms that originate in each country and the migrations that affect them. UNESCO $(2009$, p.22) pointed out that culture "can no

\footnotetext{
${ }^{1}$ Alehop has received the Award for Outstanding Action (2010), the European Label for Innovation in Language Teaching and Learning (2011), the Vicente Ferrer National Award for Development Education (2013) and the Award for Good Practices for Educational Success (2014). Alehop has been presented to public organisations and national and international universities for debate and dissemination. It also participates in national teacher networks and European research projects such as the NELLIP project.
} 
longer be reduced to a single model or conceived in terms of fixed representations". As Bernstein (1961) explained, cultural, not individual, attributes determine the acquisition of intellectual and social competences that condition success in school. The initial social and economic conditions of the collective must be included in the analysis of the situation.

At the same time, language is a paradigmatic example of these cultural representations for various reasons: 1) The evident relationship between language and culture (Whorf, 1956; Vygotsky, 1999; Luria, 1985) that shapes the way of thinking and seeing reality (Gumperz \& Levinson, 1996) or in Sapir's words (1949, p.69), "we see and hear and otherwise experience very largely as we do because the language habits of our community predispose certain choices of interpretation". Interpretations supported by experiences such as those of Everett (2005), who after living with an indigenous Amazonian tribe, concluded that the linguistic peculiarities of their language were also reflected in their culture. 2) In turn, oral and written language plays an important role as a form of communication in school culture (Rockwell, 2006), in the same way that Catalan is considered a language and Andalusian - which is just that, and with greater reason - is not; it is a question of political and not purely linguistic interest as we have been led to believe (Gutier, 2006). The Andalusian language is a more evolved form of Castillian; it is richer in vocabulary (since it contains a greater number of Arabic words alfeizar, alcoba, aceituna, ajonjoli - for which a synonym does not always exist) and has its own grammar and phonetics.

Spanish today is a language that is widely studied as a foreign language and there are many related theoretical and practical approaches (Instituto Cervantes, 1994; Melero Abadía, 2000; Sánchez Lobato \& Santos Gargallo, 2004). Yet the same is not the case when it is considered as a second language, a situation that has been considerably less studied, and which, according to Trujillo Sáez (2002, p.1) "reflects the fact that it has not yet become an object of study and reflection, despite its social value".

However, suspicions of various kinds arise in the recognition of some languages and the denial of others. English, German and French are languages that in Europe act as oppressors of the languages of small countries like Denmark, whose linguistic and cultural identity may be threatened.

Is it not political interest that Catalan is said to be a language while this status has been denied to Andalusian or Tamazight? How can we explain that the Inuit or Sami languages have been banned and have no official recognition in Denmark and Finland? It is worth recalling that Paraguay, as a bilingual country (Guarani and Spanish), has become a benchmark for linguistic democracy, thus demonstrating the link between politics and language recognition.

$$
\begin{aligned}
& \text { Che pykasumi reveve vaekué chehegui rehóvo } \\
& \text { oúva ne ange cada pyhare che kéra jopy; } \\
& \text { rohayhúgui ai ajepy'apÿva che ne ra'arôvo } \\
& \text { michínte jepépa ndaivevuivéi che mba'embyasy } \\
& \text { Song titled "Che Pykasumi”"2 }
\end{aligned}
$$

\section{Problem and research objectives}

The exclusion of the language of a collective from the educational system could be interpreted as a form of violence because it assumes that the language has less relevance or centrality in the construction of culture, of learning. Moreover, situations in which the students do not know the vehicular (official) language of learning generate an imposition that puts students at a double disadvantage (Pérez-Jorge, 2010; 2010b). The central problem is how to favour learning in a student collective with which it is not possible to use their own language.

Therefore, the following goals were established for this study: a) design a method for teaching Spanish as a second language that includes a methodology that respects student heterogeneity in maturity, capacity, ability, willingness and mode of communication; b) strengthen, systematise and linguistically enrich the school context as the main environment for the learning of Spanish as a basic tool for integration, not only at the school and academic level but also at a social level and as a citizen; c) incorporate topics of social relevance into the daily lesson plans, with which to stimulate the acquisition of Spanish in the classroom; d) encourage access to Spanish from the earliest stages of schooling as a means to balance local inequality; e) create an environment that is

\footnotetext{
${ }^{2}$ In the Guarani language. Authors: Eladio Martínez \& José Asunción Flores. Translation:

Bereft of any solace I still love you with every sunrise, like a shadow I walk alone with my loneliness; my eyes hurt when I look at the house where you used to live, my tormented heart strains at my breast and makes me sob.
} 
linguistically stimulating in a natural way and that encourages discussion, taking advantage of natural contexts where language is a means of communication that children use to mediate, resolve or take the lead in situations they are part of and for which they provide solutions; f) use universal languages like the language of magic, tales, imagination or affection as tools that serve as a bridge between what makes us alike and what differentiates us.

\section{Research context}

The study was carried out in Melilla, a Spanish city located in North Africa. Specifically, the experience was implemented in a preschool and primary school in a poorer part of the city. "La Cañada de Hidum" is known for its high rates of illiteracy, unemployment and poverty. Most breadwinners have not even completed their primary studies (76\%). Illiteracy in Spanish does not only affect the Spanish population but also others, making the language barrier the primary reason for the acute social exclusion suffered by $40.2 \%$ of the homes in the area, according to sociological studies (Segura Vázquez 2009 \& Rontomé \& Canton, 2009).

Moreover, Tamazight is the mother tongue of the majority of students enrolled in the school. ${ }^{3}$

Language policy decisions have forced students to undergo the teaching and learning process in a language that corresponds to their national, but not to their linguistic, identity. Furthermore, due to their economic situation, part of the teaching and learning process involves cultural socialisation that seeks to alleviate deficiencies associated with experiences of exclusion, from ethnocentric approaches.

In addition to the above, the educational indicators in Melilla are a cause for concern and have given rise to agreements and studies to determine causes and actions. One such study was carried out by the team of Sánchez Fernández (2010), and pointed to the high percentage of Amazigh students with poor results in Spanish language that ended up dropping out of school.

\section{Methodology}

Our study focuses on two basic areas: collaboration between university and school and action research as a theoretical and practical working process that facilitates reflection on a teacher's practice, what we might call a methodological metareflection.

\subsection{University and School Collaboration}

In response to the complex educational situation described above, the education authority commissioned a teacher from the CEIP León Solá school in Melilla to develop a programme to improve Spanish language competence. After a first assessment of the situation, the teacher proposed that the tool should be the result of a comprehensive study of context and needs. Finally, in collaboration with the ICUFOP research group ("Curriculum Research and Teacher Training") of the Junta de Andalucía, and within the framework of an action research model in which the teacher reflected on her own practice (Schön, 1992) in collaboration with other researchers, this research methodology was chosen as a tool to improve educational practice (Sandín, 2003; Pérez-Jorge, Barragán \& Molina-Fernández, 2017). The Alehop programme was designed as a result of this study.

\subsection{Development of Alehop: action-reflection-action}

We started a process of reflection and action on the practice of the project's creator, which allowed us to cast a critical and scientific eye over the work she herself was carrying out in Alehop. The teacher modified her practice in line with the findings of the action research process. The same philosophy holds true for students who use enquiry-based learning (Education Development Center, 2016) to learn the new language by exploring a relevant problem that is not resolved by the prescribed curriculum. As an example of this procedure we have copied an extract from the teacher's class journal below:

"We discovered on arriving at school that once again during the weekend some people had broken in, causing obvious destruction and stealing from one of the preschool class buildings. The subject of the robbery has been a triumph today in chats with the children [...] But when we discussed the issue of our role in everything that was

\footnotetext{
3 Tamazight is a native North African language, probably of Phoenician origin, with an oral tradition and thousands of years of history. It is unrelated to Arabic and is, above all, a fundamental part of the identity and culture of the Amazigh people (Gonzalbes Gravioto, 1994; Hart, 1983; Onrubia Pintado, 2000). Amongst this language's attributes, Chaker (1994) underlined its status as a minority or rural language. However, this description does not apply to Melilla, where more than half of the population use it in their daily lives and in an urban context.

Tamazight plays an important role in the daily lives of thousands of people in the city, although it is not recognised as an official language. In fact, the Council of Europe (2012, p.5), in the ratification and implementation of the European Charter for Regional or Minority Languages, stressed the need to "clarify the status of, and where appropriate adopt measures, in co-operation with the speakers, to protect and promote the following languages".
} 
happening, when we asked what we could do, none shied away from their responsibility, none shied away from their role and their power as a citizen to act and the proposals came thick and fast:

- We can tell them not to steal.

- We can tell them to rob their own home.

- We can tell them to steal in Barcelona.

- We can make posters to tell them.

And we ended up making posters to "tell" the thieves why we did not want them to rob our school. At the end of the day, debris still needed to be swept away but we were already sticking the posters on the wall of the school." Molina-Fernández (2012, p. 146).

Investigating one's own practice to modify it and enquiry-based learning are two distinct but complementary strategies. They have been applied because of the inability of traditional strategies to respond to the complexity of the situation and to the linguistics in a way that tackles the social and economic situation of the intervention contexts.

However, the proposed innovations have been controversial for some teachers because they have questioned consolidated traditional practices related to teaching, learning, evaluation and even the role of students and teachers.

Many of the questions that emerged during the reflection on practical action were discussed with the ICUFOP research group. There were interesting debates about the idea of childhood as constructed by the school organisation: with regard to the type of relationship established between students and teachers or its consequences for the development of the programme. On the basis of these debates, action proposals were agreed upon as provisional hypotheses so that they could be put into practice and analysed later. In short, this working approach started with the actual context and was modified and improved through the teaching practice itself; starting at the bottom and progressively ascending step by step.

This methodology was developed from the beginning of the programme in 2009. During this period, at least two clear periods may be highlighted. The first, in which there were numerous debates, meetings and proposals, coincided with the beginning of the study and the establishment of the working methodology. The second, which extends to the present, is a period during which the methodology was strengthened, and many of the proposals and findings were consolidated; proposals for reflection and analysis were less in number but equally intense. The theoretical reflection was enriched with the contributions of the enquiry- or problem-based theories of learning (Spronken-Smith \& Walker, 2010).

\subsection{Tools}

The material for reflection was compiled through audiovisual recordings and journal entries (Elliott, 2005). In the development of the action, there is little time for reflection (Perrenoud, 2004) because most of the time has been used in the action itself and in managing the events that arise. Therefore, the recordings allowed the teacher to review her practice from the outside, without the urgency of the everyday, observing situations that had gone unnoticed. In turn, the journals were used to set down the evolving reflections and provided evidence of the process through which practice was transformed. In parallel, this work was shared in work meetings, academic meetings and through scholarly publications.

The topics that were analysed included: the forms of participation that were brought about and the meaning thereof; the forms of relationships with students and the consequences thereof; and the implications that the way in which childhood is perceived had for teaching practice.

These learning processes shaped the methodological principles of Alehop. Our contribution consisted in offering support and in acting as mediators so that the complexity of children's thoughts could be better understood by means of a communication tool.

\subsection{Procedure}

\subsubsection{Organization}

Alehop is based on two weekly sessions per class. About 200 students between the ages of three and five participate each school year. One of the sessions takes the form of an assembly for all the children in the classroom to participate. For the second session students are organised in such a way that a small mixed group stays in the classroom while the rest of them are set other tasks. The small group is arranged in a heterogeneous and dynamic way, allowing the participation of different groups of students within the same session. The 
proposed activities are open enough to enable everybody, whether they have the appropriate communicative competence or have just started acquiring it, to participate.

\subsubsection{Development of the programme}

Alehop makes use of an integrative methodology, that is to say, it works with every single student in each class, embracing linguistic diversity and the different levels of communicative competence. These sessions prompt communicative situations which allow for discussion and reflection on issues of interest to the children. These students are not familiar with the language of instruction within their learning environment at school but are very experienced in overcoming complex situations even at very early ages. The process of teaching and learning Spanish with Alehop was designed to make use of the conversation contexts generated to reflect on social reality with the children.

The sessions that were developed with the students were based on five basic principles: a) giving voice to children as key agents for change; b) we learn through topics of social interest; c) from ordinary, everyday activities to more global ones; d) an atmosphere of trust and confidence to express oneself with freedom; e) from universal languages to dialogue and linguistic and communicative diversity. What follows is a detailed description of the strategies and activities carried out to implement the abovementioned methodological principles.

\subsubsection{Giving voice to children as key agents for change}

Firstly, it is only possible to learn to speak a language by speaking it in a social situation (Hymes, 1984). Thus Alehop should be above all a space of communication and dialogue. A horizontal communicative exchange where both children and teachers might exchange ideas in a process of natural conversation that constitutes the basis of learning Spanish. To do this, "all the activities that the child performed (during Alehop) were directed towards the active use of Spanish" (Viña, 2009, p.57).

Secondly, you only wish to speak when you really feel listened to, and listening can be a catalyst for change (Rudduck \& Flutter, 2007). So, in the context of the programme, the ideas and proposals that the children raised were taken into account. Their interests were also taken into account to address the different issues. In short, we tried to address individuality because "belonging to the Amazigh linguistic community does not necessarily imply a wider cultural community" (Hernández Muñoz, 2014, p. 115).

With Alehop we leave behind the idea of childhood as being resourceless and work to project an image of boys and girls who are able to reflect, converse and express their opinions, providing clever and simple ideas about complex realities which are not alien to them. Group discussions allow for the dismantling of previous assumptions or pre-conceived ideas. It also helps children deal with personal cognitive conflicts with the help of ideas provided by other people while contributing, through communication, to the acquisition of the new language.

Throughout the process of research we came to realise how high a value the children placed on the discussion topics that interested them. This aspect was one of the most difficult to achieve because it involved breaking the teacher-student vertical relationship and stimulating the student to critique professional practice itself (Elliott, 2005). This was fundamental as a first step towards awareness of its central role in the transformation of reality. However, we concur with De la Herrán (2015, p.103), when he states that "adult society expects little from the child, who is seen as little more than that, a child". In fact, the opinions and wisdom of children are often neglected in decision-making, even when the decision affects them directly. It should be added that "the social classes that most need their children to be prepared for life do not have the political means to defend their interests in the school debate" (Perrenoud, 2012, p.189). And so, on the one hand, there is a need to involve children in the decision-making process and, on the other, to put into practice dynamics of critical reflection on their own social realities. Seen in this light, education professionals are also responsible for providing spaces and tools for the practice of citizen values.

\subsubsection{Learning from topics of social interest}

Progress on the programme does not follow linear grammatical aspects, but rather places language use and functions at the centre through emerging themes that interest the children. From a grammatical point of view the question "When is the traffic light green?" [¿Cuándo está verde el semáforo?] is similar to "When is your mother sad?" [¿Cuándo está triste tu madre?]. However, there might be differences between them as to the content of the answers or the related topics to which they refer. From Alehop it is our aim to suggest, reflect on and question issues of interest as a basis for the learning of the Spanish language. It is not just a matter of speaking but also of reflecting on what it is that we are going to discuss and our role regarding the issues we address. 
Working in this way meant overcoming the view of children as incapable, unable or invisible and recognising the usefulness of, and the collective lessons that can be learned from, listening to children (Tonucci, 2006).

\subsubsection{From ordinary, everyday activities to more global activities}

Although oral expression plays an essential role at the school level, it is not often used in the academic context of curricular content. Alehop provides a space for conversation and the exchange of ideas on relevant topics which, on many occasions, stem from daily routines or common problems that concern us.

A situation related to dress code, hygiene or eating habits makes us wonder what these realities are like in other places or even amongst ourselves. A row over an empty seat may be an excuse to discuss how to resolve conflicts and express our feelings assertively. Attempts were made to use their immediate environment and their lives as initial tools in the process of learning Spanish, but also for the construction of a context of dialogue and participation (Agud, Novella \& Llena, 2014).

\subsubsection{An atmosphere of trust and confidence to express oneself with freedom}

The school must, according to Falk (2008) satisfy essential needs, including: affective security; respect and support; self-awareness; wellbeing and physical health. Of all these aspects, affective security played an important role in the process of communication and learning Spanish. To be able to get one's message across effectively, it is not only necessary to know the language but also to trust your interlocutor, making sure that they show an interest in listening and that the exchange will be constructive. Moreover, an effort should be made to share that feeling of inwardness and apathy that is a consequence of the economic and social obstacles to hope and action in the local context. That is why Alehop is committed to creating an environment of trust, confidence and active listening.

The success of conversation and participation is mediated by the climate that is created. This is what Agud, Novella \& Llena (2014, p.87) referred to when they spoke of the elements that children consider necessary for the success of experiences that give them a voice. The children emphasised "the lived experience, the climate that favours relationships, and the subjective wellbeing of the child".

\subsubsection{From universal languages to dialogue}

Children are constantly communicating messages even before they learn their mother tongue. If we look at how children who do not share the same linguistic code relate to each other, we will find that they resort to other forms of relationship or play. Those instances of language are embraced by Alehop to be used as a springboard towards verbal expression. This way of understanding communication puts an end to those barriers built by adults, who consider children, due to their age, incapable of participating in many thought and decision-making processes. Instead, Alehop takes account of gestures, body language, facial expressions, games, tales, music, drawings, imagination, fantasy, etc., in the process of communication. Fantasy and imagination play different roles in the programme. Alehop, as a character, dressed in a funny way, conveys the fantasy of the tales to the children as well as sharing with them the language of imagination. The aim is to eliminate all barriers that may hinder the effective participation of the students. In addition, different languages are used simultaneously during the sessions with a view to ensuring the inclusion of all the children in the classroom when there are different levels of communicative competence.

We could also focus on their use of universal languages, their communicative strategies, the way they participated and listened, etc. By listening to the children we learned that for many of them hunger was their daily bread, so we started to think about how to improve their communicative competence, making sure to incorporate topics of social relevance.

We took advantage of the sessions where the children's participation was particularly high to learn to listen to them not just with our ears.

\subsubsection{Linguistic and communicative diversity}

All children aged from three to six attending the school participate in Alehop. That way, we incorporate strategies that take account of the linguistic and communicative differences, and which help us learn at the same time how to deal with them so that they do not turn into a barrier or a problem.

However, participation in any stage of the project is voluntary since it is not our intention to force anybody to take part, but rather to create an appropriate environment for anyone who wishes to do so.

Children who share the same level in the classroom differ in many respects, also in the way they communicate and regarding their linguistic skills. That is why we rejected the idea of a linear, sequenced and gradual formula. Instead, we opted for an experience that can offer a multilevel response which supports those who have just 
started the process of acquisition of communicative competence as well as those who are already competent in this skill. To achieve that, students act as role models for each other, collaborating together in the acquisition of language and communicative competence.

\subsubsection{Evaluation}

Each year we devoted the month of October to carrying out the initial assessment and the month of June to the final assessment. To this end, we made use of similar strategies to those employed in the sessions and observed the way children communicate as well as their attitude and the content of their communicative exchanges. It is an authentic assessment (Burke, 2009) with a communicative approach that is conducted through natural conversations with adults and the observation of communication between peers to eliminate the negative effects of the test-type evaluations described by Labov (1969). We colour-coded the data obtained using the same codes that teachers use to communicate when a goal has been achieved (green), is in the process being achieved (yellow), or has not been achieved (red).

The results were then classified into three levels according to the descriptors established for each level of competence by the Common European Framework of Reference for Languages (Council of Europe, 2002).

The qualitative evaluation was carried out on a daily basis during the sessions to assess the development of the programme, for example, in those sessions conducted by both teachers, where one of them takes charge of monitoring the learning process. In the other sessions we used indicators to record whether or not all the children participated. This is a simple method that allows us to ensure the participation of all the students according to their level. In addition, we used conversation and observation sessions during both the initial and final stage of assessment to obtain samples of oral exchanges between the children and establish three levels based on the descriptors of the Common European Framework of Reference for Languages: A1, A2, B1, etc. (Council of Europe, 2002). This evaluation method made it possible to assess the impact of the programme in each case and provide a longitudinal analysis over time.

We also conducted a review of our concept and evaluation method with the aim of incorporating the issues of social relevance that children were interested in into the programme and into the Spanish language learning process. Thus, a comprehensive (Stake, 2006), continuous evaluation was undertaken, offering a broader understanding of the communicative possibilities of each student. The aim of this evaluation was to understand the general context of the child and the repercussions for their possibilities of communicating, first, and acquiring Spanish, second. The evaluation was understood to be a process that presented a way of looking at the students, of being with them and of being interested in what they were and wanted to be. It signified having an interest in knowing them, listening to them or engaging with their concerns. It meant acknowledging the specificity of each case and a willingness to readapt the evaluation as needed. It neither reduced nor simplified the process to a number or a result, which made the task much more complex but at the same time made it possible to engage the students much more deeply with reality.

\section{Findings, conclusions and limitations}

Alehop may be considered good practice inasmuch as it produces promising quantitative results in the development of communicative competence every academic year. The qualitative assessment is also excellent, as demonstrated by the children's great enthusiasm for conversation and interaction.

Although the Alehop programme was implemented to improve communicative competence in Spanish, in practice it meant much more than just talking. As an example of this, an occasion comes to mind during a session with the families where I explained that there were no teachers to implement the experience in the fourth year. At this moment a child who had participated in Alehop since he was three years old interrupted me, uttering a loud "WHAT?", and burst into tears because he could not believe his ears. We want to emphasise that Alehop means much more than just talking or interacting because, even though the aim is to improve communicative competence, the whole process has yielded even more important achievements than that. The fact that children are willing to express themselves, to talk, to say things, to discuss, to contribute, to participate, to challenge themselves, bearing in mind the deprived areas that they come from, characterised by such high rates of social exclusion, means that they have shown a real willingness to take part, to be a piece in the shared construction of the community. Moreover, the project endows them with the skills needed to then be able to express their complex ideas through writing or to gain access to written texts.

In addition to the role of the students in the programme, Alehop has been an example throughout the years of incorporating reflection and action as strategies for improving teaching practice. This combination is not due to mere chance but is the result of years of pondering, research and action between the teacher and the university, 
which has led to a relationship of such close collaboration that it is difficult for her to keep her professional career as a school teacher separate from her research work on the curriculum and teacher training. The programme therefore is a medium through which to transfer the knowledge generated during research.

The importance that the teacher places on the role of training in the Alehop methodology lies in the need of the teacher to combine two crucial qualities: on the one hand, the ability to stimulate children to talk about, and express themselves on, topics of interest to them, that are relevant to them and that awaken their critical thinking. In addition, the teacher must have a knowledge of, and be able to use, the levels of competence as described in the Common European Framework of Reference for Languages (Council of Europe, 2002) in order to provide each child with appropriate support since she will have to deal with students with very different levels of competence in the same class, from those reluctant to talk to others to those with a B1 level, for example.

On the other hand, beyond the methods and techniques used, the educational commitment in the programme was relevant in the search for answers adapted to the social context and responsive to the needs and demands of this social group. Working in unfavourable contexts where the main factors are poverty and social exclusion requires the involvement of people committed to change, equity and social justice. With regard to research, this commitment stems from an interest in sharing and transferring the knowledge gained to other agents and contexts where it may be useful.

Data from the first initial evaluation, before implementation of the programme, showed that $57.8 \%$ of the three-year-old students enrolled at the school did not show an intention to communicate orally, either in Spanish or in their mother tongue. $18.6 \%$ of students enrolled at the age of three had a level of Spanish appropriate for their age. The variability of the groups in each school year also affected the results that were obtained, since at the beginning of and during each school year, new children joined the school without any knowledge of Spanish. The levels of knowledge of Spanish acquired by the children through the fact that they go to school were insufficient. Thus, at three years of age it was estimated that $18.6 \%$ of children attained level A1 in communicative competence in Spanish; at four years this rose to $37.9 \%$, and at five years, to only $40.5 \%$.

With regard to the data obtained after the first year of the Alehop programme, it was observed that results improved at all levels. For three-year-olds, from the initial 18.6\%, 48.4\% of children reached a level of Spanish consistent with their age. For four-year-olds this rose to $54.6 \%$, and for five-year-olds, $58.5 \%$. The values obtained by implementing the programme for three-year-olds exceeded the values schooling alone had achieved five years before implementation of the programme. The figures for the red level, which corresponds to scarce verbal communication and non-acquisition of Spanish, reduced significantly for each age group. The decrease is more marked the lower the age of the students. Thus, for three-year-olds the initial level of $57.8 \%$ fell to $14.1 \%$, which represents a reduction of $43.7 \%$, compared to the reduction of $7.5 \%$ achieved amongst five-year-olds.

Table 1. Initial and final evaluations for the first Alehop programme

\begin{tabular}{|c|c|c|c|c|}
\hline & Red & Yellow & Green & \\
\hline Initial & $57.8 \%$ & $23.6 \%$ & $18.6 \%$ & \multirow{2}{*}{ three-year-olds } \\
\hline Final & $14.1 \%$ & $37.5 \%$ & $48.4 \%$ & \\
\hline Initial & $42.3 \%$ & $19.8 \%$ & $37.9 \%$ & \multirow{2}{*}{ four-year-olds } \\
\hline Final & $13.6 \%$ & $31.8 \%$ & $54.6 \%$ & \\
\hline Initial & $26.8 \%$ & $32.7 \%$ & $40.5 \%$ & \multirow{2}{*}{ five-year-olds } \\
\hline Final & $19.3 \%$ & $22.2 \%$ & $58.5 \%$ & \\
\hline
\end{tabular}

The cultural traits (Bernstein, 1961) of the students are the basis of dialogues for practising new language skills. Conversations that take a critical view of society and contribute to the construction of students' culture and thinking (Whorf, 1956; Gumperz \& Levinson, 1996).

With regard to achievements related to language acquisition, it should be noted that the programme improved the students' level of Spanish both for those that already spoke the language and amongst those who did not express themselves orally in the classroom. In fact, the benefit of schooling for the acquisition of language was enhanced when students were offered sessions with a methodology that approached the learning of a second language from the perspective of communication. For example, we observed the green level (corresponding to A1) in $40.5 \%$ of five-year-old students when they had not participated in the programme. In the case of four-year-olds, who have been at the school for less time, after participating in the programme they out-performed the five-year-olds, with 
54.6\% achieving the green A1 level. The same was observed in the case of the three-year-olds who, after participating in the programme, scored better $(48.4 \%)$ than the children who had been in school for a year more before participating in the programme $(37.9 \%)$.

Furthermore, Spanish language competence improved markedly in those cases in which the Alehop programme was implemented at an early stage. This early approach was not at odds with the inclusion of social issues that were meaningful to the children, such as sexist violence or theft-related problems in the neighbourhood. Thus, the acquisition and learning of Spanish could be approached from the earliest ages, based on relevant themes that are of interest to the children, and this turned the learning of Spanish into just one more learning process. In addition, the comprehensive approach to communication that was adopted by the programme contributed to the development of a climate conducive to the learning of the new language in school contexts of linguistic diversity. Although the status quo established by language policies has not given equal footing to the languages spoken in the classroom, the educational ecosystem created by the Alehop programme has provided a context in which to construct and analyse reality without undermining cultural identity.

The teaching commitment in socially disadvantaged contexts provided compelling evidence to an educational community that has traditionally given greater credibility to the proposals, methodologies and learning that are acquired in the school.

Moreover, the Alehop programme has given form to the collaboration between school and university. In itself it has provided an opportunity to initiate processes of reflection-action and research that become tools for lifelong learning and for improving teaching and learning processes.

A constructive next step would be to collect data for a full period of the programme and data from a longitudinal study in order to analyse the effect of the programme on a full schooling cycle.

\section{References}

Agud, I., Novella, A. M. \& Llena, A. (2004). Las condiciones y características de la participación infantil auténtica. En Novella, A.M.; Llena, A.; Noguera, E.; Gómez, M.; Morata, T. y otros. Participación infantil y construcción de la ciudadanía (pp.73-90). Barcelona, España: Graó. https://books.google.es/books?hl=es\&lr=\&id=1dOcCQAAQBAJ\&oi=fnd\&pg=PA9\&dq=Agud,+I.\%3B+No vella, + A. + M. + y+Llena, + A. $+(2004) .+$ Las + condiciones $+\mathrm{y}+$ caracter $\% \mathrm{C} 3 \%$ ADsticas + de + la + participaci\%C 3 $\%$ B3n+infantil+aut\%C3\%A9ntica.+\&ots=kbomK-bKRE\&sig=vHkMmn-wzhiJB8CYrP1tT3BugaQ

Bernstein, B. (1961). Social class and linguistic development, a theory of social learning. In A. H. Halsey, J. Floud, C.A. Anderson (Eds.). Education, economy and society. New York: Free Press. http://www.tandfonline.com/doi/pdf/10.1080/0013188610030301

Burke, K. (2009). How to assess authentic learning. Sage: London. https://books.google.es/books?hl= es\&lr $=\& \mathrm{id}=\mathrm{CHo} 9 \mathrm{q} 56 \mathrm{p}-\mathrm{JsC} \&$ oi $=$ fnd\&pg $=$ PR1\&dq $=$ Burke,$+\mathrm{K} .+(2009) .+$ How + to + assess + authentic + learnin g. + Sage: + London.\&ots=OMuPUBiCpm\&sig=oxWFSEhyTk6jS8BB-m3aDrlzTWk

Council of Europe (2012). European Charter for Regional or Minority Languages. 3rd Monitoring Cicle. http://www.coe.int/t/dg4/education/minlang/Report/EvaluationReports/SpainECRML3_en.pdf

(2002). Marco Común Europeo de Referencia para las lenguas: aprendizaje, enseñanza y evaluación. Madrid: Secretaría General Técnica del MECD y Grupo Anaya.

Chaker, S. (1994). El bereber en el Magreb. Una marginación dos veces milenaria. (Dificultades de la planificación lingüística). En Raha Ahmed, R. (Ed.). Imazighen del Magreb entre Occidente y Oriente. Introducción a los bereberes (Pp. 105-116). Granada: Rachid Raha.

De la Herrán, A. (2015). ¿El niño como maestro? En Villena Higueras, J.L. y Molina Fernández, E. Ciudades con vida: Infancia, participación y movilidad. Barcelona: Graó. https://books.google.es/books?hl=es\&lr=\&i $\mathrm{d}=\mathrm{Hp} 0 \mathrm{gCAAAQBAJ} \&$ oi=fnd\&pg $=$ PA103\&dq $=$ De + la + Herr $\% C 3 \% A 1 \mathrm{n}+\mathrm{Gasc} \% \mathrm{C} 3 \% \mathrm{~B} 3 \mathrm{n},+\mathrm{A} .+(2015) .+\% \mathrm{C}$ 2\%BFEl+ni\%C3\%B1o+como+maestro\%3F+\&ots=QaDS0u-OiZ\&sig=RPrrXCQvJkhEX24UZQUsrj9r-F4

Durkheim (1976). Educación como socialización. Salamanca: Sígueme. http://jorgecapellariera.com/wp/wp-c ontent/uploads/2013/02/Blog-2-La-educaci\%C3\%B3n-su-naturaleza-y-su-funci\%C3\%B3n-E.-Durheim.doc

Education Development Center (2016). Inquiry-based learning: an approach to edudcating and inspiring kids. www.youthlearn.org

Elliott, J. (2005). El cambio educativo desde la investigación-acción. Madrid: Morata.

Everett, D. L. (2005). Cultural constraints on grammar and cognition in Piraha: another look at the design 
features of human language. Current anthropology 46, 621-645. http://www.jstor.org/stable/10.1086/ 431525? seq=1\#page_scan_tab_contents

Erickson, F. (1987). Transformation and school success: The politics and culture of educational achievement. Anthropology and education quarterly, 18 (4), 335-356. http://www.jstor.org/stable/3216661? seq=1\# page_scan_tab_contents

Falk, J. (Ed.). (2008). Lóczy, educación infantil. Barcelona: Octaedro.

Gonzalbes Cravioto, E. (1994). Los orígenes del pueblo bereber. La antigüedad clásica. En Raha Ahmed, R. Imazighen del Magreb entre Occidente y Oriente. Introducción a los bereberes (pp. 19-39). Granada: Rachid Raha. http://revistas.ucm.es/index.php/GERI/article/download/GERI0202120451A/14297

Grimson, A. (2008). Diversidad y cultura: reificación y situacionalidad, Tabula Rasa, 8, 45-47. file:///C:/Users/Usuario/Downloads/1718-5740-1-PB.pdf

Gumperz, J. J. \& Levinson, C.S. (1996). Rethinking linguistic relativity. Cambridge University Press. http://www.journals.uchicago.edu/doi/pdfplus/10.1086/204009

Gutier, T. (2006). En defensa de la lengua andaluza. Almuzara: Córdoba.

Hart, M. D. (1983). Los bereberes marroquíes: dialectos, organización tribal e instituciones sociales. En VV.AA. Aproximación a las culturas mediterráneas del norte de África (I): Conclusiones de las Primeras Jornadas de Cultura Hispano-Bereber (pp.145-157). Melilla: Publicaciones de la Escuela Universitaria del Profesorado de EGB.

Harris, M. (2011). Antropología cultural. Madrid: Alianza Editorial. https://www.ucm.es/data/cont/docs/ 226-2016-09-27-Antropolog\%C3\%ADa\%20del\%20G\%C3\%A9nero.\%20Beatriz\%20Monc\%C3\%B3.pdf

Harris, M., \& Sempere, S. J. (2000). Teorías sobre la cultura en la era posmoderna. Barcelona: Crítica. http://www.academia.edu/download/33709955/Harris_Marvin_Teorias_Sobre_La_Cultura_En_La_Era_Po smoderna.DOC

Hernández Muñoz, N. (2014). El choque intercultural en español. Perspectivas desde la formación de profesores de E/LE. Porta Linguarum, 109-126. http://www.ugr.es/ portalin/articulos/PL_numero22/8\%20\%20NATIVIDAD\%20Hernandez.pdf

Hymes, D. (1984). Vers la competénce de communication. Paris. Hatier. http://archives.umc.edu.dz/handle/123456789/112015

Instituto Cervantes (1994). La enseñanza del español como lengua extranjera. Plan curricular del Instituto Cervantes. Madrid, España: Publicaciones del Instituto Cervantes. http://cvc.cervantes.es/ensenanza/ biblioteca_ele/publicaciones_centros/PDF/rio_2007/48_sanchez-garcia-marco-maresma.pdf

Keesing, R. (1993). Teorías de la cultura. En H. M. Velasco (Comp.). Lecturas de Antropología Social y Cultural (pp. 51-82). Madrid, España: UNED.

Labov, W. (1969). The logic of nonstandard English. Georgetown monographs on language and linguistics, 33, 1-31. https://www.cambridge.org/core/journals/language-in-society/article/the-linguistic-consequences-ofbeing-a-lame/F016BB32CAE82BFA757AB953224597D3

Lévi-Strauss, C. (1958). Antropología estructural. Buenos Aires: EUDEBA.

Luria, A. R. (1985). Lenguaje y pensamiento. Barcelona, España: Martínez Roca.

Melero Abadía, P. (2000). Métodos y enfoques en la enseñanza/aprendizaje del español como lengua extranjera. Madrid, España: Edelsa. file:///C:/Users/Usuario/Downloads/Dialnet-LaEnsenanzaDeEspanolYLaForm acionDelDocenteDeEspano-1709360.pdf

Molina-Fernández, E. (2012). La construcción de la infancia de origen amazigh en la escuela: Estudio de caso en la ciudad de Melilla (Doctoral dissertation). Unviersidad de Granada, Granada: España http://digibug.ugr.es/handle/10481/23796

Onrubia Pintado, J. (2000). De etnogénesis bereber. Algunas consideraciones acera del problema del origen de las primeras formaciones sociales bereberohablantes. En Moga, V. y Raha Ahmed, R. (Ed.). Estudios Amaziges. Substratos y sinergias culturales (pp. 13-54), Melilla, España: Servicio de publicaciones.

Parsons, T. (1973). Culture and Social System Revisited. En L. Scheneider \& C. Bonjean (Eds.). The idea of culture in the social sciences. (pp.33-46). Cambridge: Cambridge University Press. http://www.jstor.org/stable/42858956 
Pérez-Jorge, D. (2010). Actitudes y concepto de la diversidad humana: Un estudio comparativo en centros educativos de la isla de Tenerife (Doctoral dissertation). Universidad de La Laguna, Canarias, España.

Pérez-Jorge, D. (2010b). El profesor motivador: El profesor que estimula e implica a los alumnos en proyectos para el desarrollo de la competencia cultural y artística. En O. Alegre, O. (Ed.), Capacidades docentes para atender a la diversidad (pp.139-153). Sevilla, España: MAD.

Pérez-Jorge, D., Barragán, F. \& Molina-Fernández, E. (2017). A Study of Educational Programmes that Promote Attitude Change and Values Education in Spain. Asian Social Science, 13(7), 112-130. https://doi.org/10.5539/ass.v13n7p112

Perrenoud, P. (2012). Cuando la escuela pretende preparar para la vida: ¿Desarrollar competencias o enseñar otros saberes? Barcelona, España: Graó. https://books.google.es/books?hl=es\&lr=\&id=iotx1t2MbzYC\&oi= fnd\&pg=PA9\&dq=Perrenoud, + P. $+(2012) .+$ Cuando + la + escuela + pretende + preparar + para + la + vida: $+\% \mathrm{C} 2 \%$ BFDesarrollar+competencias $+\mathrm{o}+\mathrm{ense} \% \mathrm{C} 3 \% \mathrm{~B} 1 \mathrm{ar}+{ }_{\mathrm{otros}}+$ saberes$\% 3 \mathrm{~F}+\&$ ots $=$ TzM_GwBRt3\&sig=KUNVsd OORMISJVIe1RcHkbsTAwg

Perrenoud, P. (2004). Desarrollar la práctica reflexiva en el oficio de enseñar: Profesionalización y razón pedagógica. Barcelona, España: Graó. https://books.google.es/books?hl=es\&lr=\&id=0A2SnLyp_I0C\&oi=f nd\&pg $=$ PA9\&dq $=$ Perrenoud, + P. $+(2004) .+$ Desarrollar + la + pr $\% C 3 \% A 1$ ctica + reflexiva + en + el + oficio + de + en se $\%$ C3\%B1ar:+Profesionalizaci\%C3\%B3n+y+raz\%C3\%B3n+pedag\%C3\%B3gica\&ots=mVMEq DEQL\& sig=hQ06-Zxpvjvhl5eSMO5yNsxIoOw

Rockwell, E. (2006). La dinámica cultural en la escuela. En Álvarez, A. (Ed.) Hacia un currículum cultural: la vigencia de Vygoski en la educación (pp. 21-38). Madrid, España: Fundación Infancia y Aprendizaje. http://www.redalyc.org/pdf/354/35450902.pdf

Rontomé, C. \& Cantón J.M. (2009). Las condiciones de vida de la población pobre de la Ciudad de Melilla. Un estudio comparativo 1995-2009. Sociópolis: Inédito.

Rudduck, J. \& Flutter, J. (2007). Cómo mejorar tu centro escolar dando la voz al alumnado. Madrid, España: Morata. https://books.google.es/books?hl=es\&lr=\&id= hOUKs01JNEC\&oi=fnd\&pg=PA11\&dq=Rudduck, $+\mathrm{J} .+\mathrm{y}+$ Flutter, $+\mathrm{J} .+(2007) .+\mathrm{C} \% \mathrm{C} 3 \% \mathrm{~B} 3 \mathrm{mo}+$ mejorar $+\mathrm{tu}+$ centro + escolar + dando $+\mathrm{la}+\mathrm{voz}+\mathrm{al}+\mathrm{alumnado} . \& o t s=$ fn-uOjN3Ew\&sig=7odSxDxIBIuIR4_NxbxO2bQSz3s

Sánchez Fernández, S. (Dir.) (2010). Abandono escolar temprano en las ciudades de Ceuta y Melilla. Madrid, España: Ministerio de Educación. https://books.google.es/books?hl=es\&lr=\&id=vDJiCAAAQBAJ\&oi=fnd \&pg=PA9\&dq=S\%C3\%A1nchez + Fern\%C3\%A1ndez, + S. + (Dir.) $+(2010) .+$ Abandono + escolar+temprano $+e$ $\mathrm{n}+$ las + ciudades + de + Ceuta $+\mathrm{y}+$ Melilla. $+\&$ ots $=$ NVzjxgQwVF\&sig=yZ_4NLT9NBfkdx7ijczJdWzqrCs

Sánchez Lobato, J. \& Santos Gargallo, I. (2004). Vademécum para la formación de profesores. Enseñar español como segunda lengua (L2) / lengua extrajera (LE). Madrid, España: SGEL. https://www.mecd.gob.es/dam/j cr:b5a5aa14-3229-4175-baa4-aecdd3e6bd11/2004-redele-1-res-santos-pdf.pdf

Sapir, E. (1949). Culture, Language and Personality. The regents of the University of Calfornia.

Schön, D. (1992). La formación de profesionales reflexivos. Hacia un nuevo diseño de la enseñanza y el aprendizaje en las profesiones. Barcelona, España: Paidós. http://csmvigo.com/pedagoxia/files/2016/ 07/D.A.-SCH\%C3\%96N-LA-FORMACI\%C3\%93N-DE-PROFESIONALES-REFLEXIVOS.pdf

Segura Vázquez, P. (2009). Pobreza y exclusión social. Diagnóstico de los distritos 4 y 5 de Melilla. Informe inédito encargado por el Ministerio de Trabajo e Inmigración, el INEM y Acción Social Sin Fronteras. https://eapnmelilla.files.wordpress.com/2011/01/pobreza-y-exclusic3b3n-social-un-diagnc3b3stico-de-los-d istritos-4-y-5-de-melilla.pdf

Spronken-Smith, R. \& Walker, R. (2010). Can inquiry-based learning strengthen the links between teaching and $\begin{array}{lllll}\text { disciplinary research? Studies in Higher Education 35(6), } & \text { 723-740. }\end{array}$ http://dx.doi.org/10.1080/03075070903315502

Stake, R. (2006). Evaluación comprensiva y evaluación basada en estándares. Barcelona, España: Graó. https://books.google.es/books?hl=es\&lr=\&id=PLj34PiFicUC\&oi=fnd\&pg=PA9\&dq=Stake, + R. $+(2006) .+E$ valuaci $\% \mathrm{C} 3 \% \mathrm{~B} 3 \mathrm{n}+$ comprensiva $+\mathrm{y}+$ evaluaci $\% \mathrm{C} 3 \% \mathrm{~B} 3 \mathrm{n}+$ basada + en + est $\% \mathrm{C} 3 \% \mathrm{~A} 1$ ndares. $+\&$ ots $=\mathrm{BSIt} 7 \mathrm{Unw}$ 1O\&sig=xAwXvTUZNzPW5PbSvYIZ-xioJig

Tonucci, F. (Comp.) (2006). A los tres años se investiga. Buenos Aires, Argentina: Losada.

Trujillo Sáez, F. (2002). Enseñanza del español como segunda lengua: el reto de la inmigración a la didáctica de 
la lengua. En J.L. Romero Moreno y A. Camacho Herrera (Eds.). Política Migratoria y Educación Social (pp.91-98). Sevilla, España: Librería Andaluza

Tylor, E. B. (1871). La ciencia de la cultura. En J.S. Kahn (1975). El concepto de cutlura: Textos Fundamentales (pp.29-46) Barcelona, España: Anagrama.

UNESCO (2009). Invertir en la diversidad cultural y el diálogo intercultural: Informe Mundial de la UNESCO. http://unesdoc.unesco.org/images/0018/001847/184755S.pdf

Vygotsky, L. (1999). Lenguaje y pensamiento: teoría del desarrollo cultural de las funciones psíquicas. Buenos Aires, Argentina: Fausto. http://www.sidalc.net/cgi-bin/wxis.exe/?IsisScript=HAG.xis\&method=post\& formato $=2 \&$ cantidad $=1 \&$ expresion $=\mathrm{mfn}=015220$

Viña, M. (2009). Un notable antecedente del enfoque comunicativo en la enseñanza de lenguas extranjeras y de la aperture europeísta en la España de principios del siglo XX. Memoria histórica de la enseñanza de idiomas. Porta Linguarum, 11, 51-64. http://digibug.ugr.es/bitstream/10481/31831/1/VinaRouco.pdf

Whorf, B.I. (1956). Language, thought, and reality. The M.I.T. Press. Massachusetts Institute of Technology. Cambridge, Massachusetts. https://archive.org/details/languagethoughtr00whor

\section{Copyrights}

Copyright for this article is retained by the author(s), with first publication rights granted to the journal.

This is an open-access article distributed under the terms and conditions of the Creative Commons Attribution license (http://creativecommons.org/licenses/by/4.0/). 